Art and Revolution in Modern China 
This volume is sponsored by the Center for Chinese Studies,

University of California, Berkeley 


\section{Ralph Croizier}

\section{Art and \\ Revolution \\ in Modern China}

\section{The Lingnan (Cantonese) School of Painting, 1906-1951}


University of California Press

Berkeley and Los Angeles, California

University of California Press, Ltd.

London, England

(C) 1988 by

The Regents of the University of California

\section{Library of Congress Cataloging-in-Publication Data}

\section{Croizier, Ralph C.}

Art and revolution in modern China.

Bibliography: p.

Includes index.

1. Ling-nan school of painting. 2. Painting, Chinese-20th century. 3. Painting-Political aspects-China. I. Title.

ND1043.53.L55C7 $1988 \quad 759.951^{\prime 2} 27 \quad 86-31783$

ISBN 0-520-05909-3 (alk. paper)

Printed in the United States of America

$\begin{array}{lllllllll}1 & 2 & 3 & 4 & 5 & 6 & 7 & 8 & 9\end{array}$ 
Ah, but a man's reach should exceed his grasp,

Or what's a heaven for?

Robert Browning, Andrea del Sarto 
